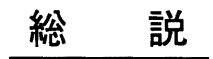

\title{
フッ素系高分子界面活性剂
}

\author{
沢田 英夫*1 $・$ 川瀬 徳三*2 \\ *1 奈良工業高等専門学校化学工学科 \\ （ (639-11 大和郡山市矢田町） \\ $* 2$ 大阪市立大学生活科学部 \\ ( 5558 大阪市住吉区杉本)
}

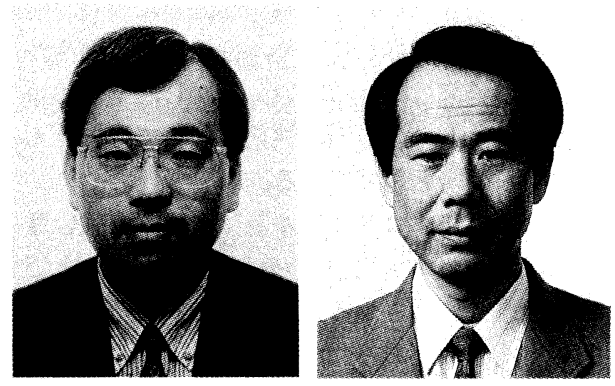

\section{Fluoroalkylated Oligo-Surfactants}

\author{
Hideo SAWADA ${ }^{* 1}$ and Tokuzo KAWASE ${ }^{* 2}$ \\ *1 Department of Chemistry, Nara National College of Technology \\ (22 Yata, Yamatokoriyama-shi, Nara-ken, =639-11) \\ *2 Faculty of Human Life Science, Osaka City University \\ (Sugimoto, Sumiyoshi-ku, Osaka-shi, ₹558)
}

\begin{abstract}
Synthesis and properties of a series of fluoroalkylated oligomers by using fluoroalkanoyl peroxides have been reviewed. The synthetic methods of fluoroalkylated acrylic acid, nonionic, and cationic oligomers were illustrated. These fluoroalkylated oligomers, in particular, fluoroalkylated acrylic acid, nonionic, and cationic oligomers were in general shown to become soluble not only in water but also in common organic solvents such as methanol, ethanol, dimethyl sulfoxide, benzene and toluene. These fluoroalkylated oligomers have quite unique structure that fluoroalkyl groups are substituted only on the both terminals of oligomer chain, and can be regarded as double-chain type surfactant. They exhibit excellent surface active properties attributable to fluoroalkyl groups, such as quite low surface and interfacial tension, and anti-foaming property, and so on.

Fluoroalkylated acrylic acid homo- and co-oligomers were demonstrated to exhibit a potent anti-HIV-1 activity in vitro. Furthermore, fluoroalkylated cationic oligomers were found to have an antibacterial activity. Therefore, these fluoroalkylated acrylic acid and cationic oligomers have been widely applicable to various fields as the novel functional materials which possess both a unique property imparted by fluorine and an anti-HIV-1 or antibacterial activity.
\end{abstract}

Key words : fluoroalkylated oligomers, solubility, surface tension, anti-HIV-1 activity, antibacetrial activity

\section{1 はじめに}

高分子界面活性剂, 特に界面活性機能を有するセグメ ントを構成モノマーとした重合体，すなわちポリソープ 型高分子界面活性剂は低分子界面活性剂には見られない 特徴, すなわち分散作用あるいは逆に凝集作用等を示す ため注目されている。しかしながら, 高分子界面活性剂 は分子が大きいため水中でミセル等の集合体を形成し難 く, 低分子界面活性剂に比べ表面張力を低下させる力は

連絡者 : 沢田英夫
一般に弱い1)。例えば，次のポリソープは cmc（臨界 ミセル形成濃度）に相当する break point を示さない ことが報告されている2゙。

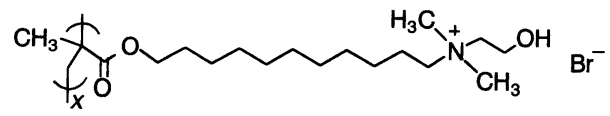

Scheme 1

一方, フッ素, 特に長鎖のフルオロアルキル基が導入 された界面活性剤は, 従来の対応する炭化水素系界面活 
性剤には見られないフッ素に起因した優れた機能を有す ることから注目されており，低分子量界面活性剂につい てはその研究は非常に多い。しかし，フルオロアルキル 基を有した高分子界面活性剤についてはほとんどなく， これからの研究領域である。

従来, フルオロアルキル基はフッ素の強い電子吸引性 のため Grignard 反応等を利用した古典的なアルキル 化法を直接適用させることができず，それ独自の手法を 開発する必要があった ${ }^{3)}$ 。従来, フルオロアルキル基は その導入が比較的容易であるエステル結合等で導入され ており，そのため，フッ素に起因した性質を長期にわた り発現させることは一般に困難とされている。フルオロ アルキル基を有するジアシルタイプの有機過酸化物 [過 酸化フルオロアルカノイル : $\mathrm{R}_{\mathrm{F}} \mathrm{C}(=\mathrm{O}) \mathrm{OO}(\mathrm{O}=) \mathrm{CR}_{\mathrm{F}}$; $\mathrm{R}_{\mathrm{F}}=$ フルオロアルキル基 $]^{4)}$ は通常のフッ素を含まな い過酸化アルカノイルに比べ, 酸素-酸素結合の反結合 性軌道準位が著しく低い5)。この特徵は, ベンゼン, ト ルエン等の芳香族化合物中の $\pi$ 電子から過酸化物の酸素 一酸素結合への一電子移動反応を可能とし, これら芳香 族環へのフルオロアルキル化が容易に進行する ${ }^{6), 7) 。 ~}$

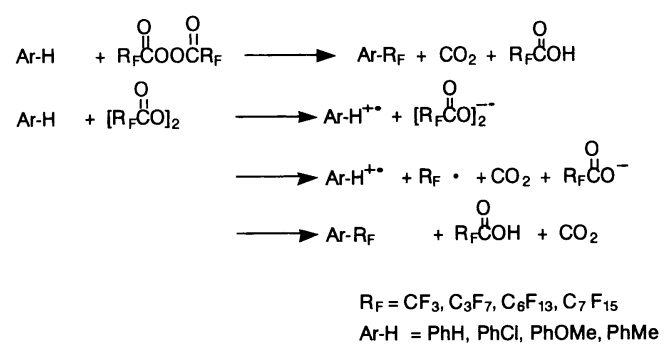

Scheme 2

過酸化フルオロアルカノイルのもう一つの特徴は, 通 常のフッ素を含まない過酸化アルカノイルは, 逐次的な ラジカル開裂によりアシルオキシラジカルを主に生成す るのに対し8), 以下のスキームに示すように熱分解によ り協奏的に 3 結合が同時開裂してフルオロアルキルラシ カルを選択的に生成する点である ${ }^{9)}$ 。

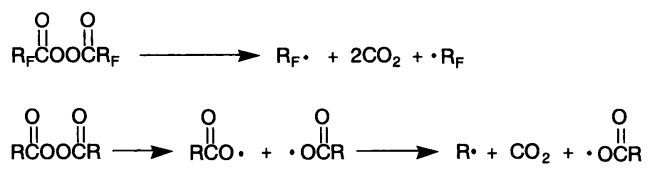

Scheme 3

このような背景から, 我々は過酸化フルオロアルカノ イルのフルオロアルキルラジカル生成能の高さに注目 し, 種々ラジカル重合性を示す基質を用いることにより ラジカルプロセスでフルオロアルキル基を直接炭素一炭
素結合で導入することを試みた。すなわち以下のスキー ムに示すように, フルオロアルキル基が直接導入された ポリマーあるいは分子量が数千程度のオリゴマーが得ら れると考えた。

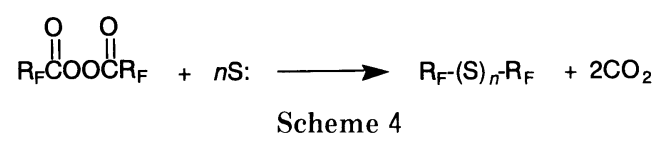

期待通り, フルオロアルキル基が両端に導入されたオ リゴマー界面活性剂が得られ，これら材料はフッ素に起 因したユニークな機能を有することが明らかになってき ている。そこで, 本総説では過酸化フルオロアルカノイ ルをキーマテリアルとした種々のフルオロアルキル基含 有オリゴマー類の合成, 溶液の界面特性さらには生理活 性等に関して我々の研究を紹介する。

\section{2 フルオロアルキル基含有オリゴマー類の合成}

\section{$2 \cdot 1$ フルオロアルキル基含有シリコンオリゴマー類 の合成}

界面活性剤という本題から少しそれるが，合成の基本 となるラジカルプロセスの説明として, 過酸化フルオロ アルカノイルとビニルシラン類との反応について紹介す る。

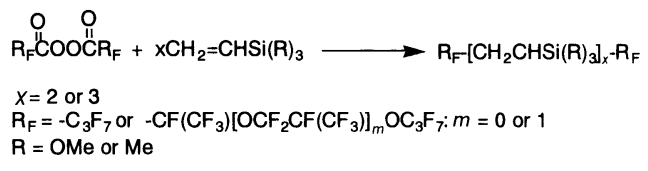

Scheme 5

過酸化フルオロアルカノイルとビニルシラン類とを反 応させると, 熱分解で生じたフルオロアルキルラジカル による一次ラジカル停止反応さらには過酸化物による生 長ラジカルへの連鎖移動が進行し, 過酸化物に起因した フルオロアルキル基が両端に直接導入されたシリコンオ リゴマーが温和な条件下にて収率良く得られる ${ }^{10) 。 ~}$

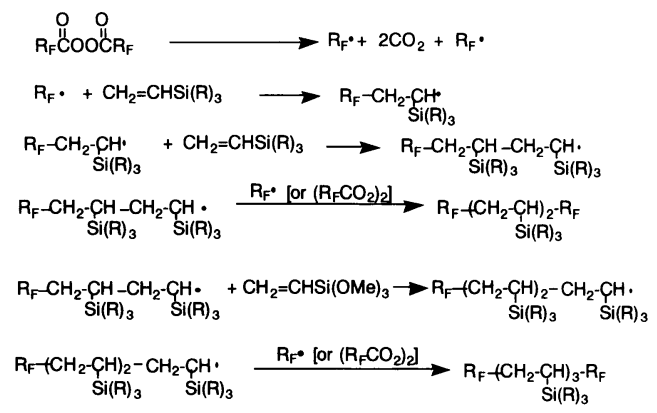

Scheme 6 
この中で，特にメトキシル基を有するフルオロシリコ ンオリゴマーははっ水, はつ油性を示すフルオロシラン カップリング剂として有望であることを見いだしてい る11)。

\section{$2 \cdot 2$ フルオロアルキル基含有アクリル酸オリゴマー} 類の合成

ラジカル重合性の高いモノマーであるスチレンはHOMO のエネルギー準位が高く $(-9.132 \mathrm{eV})$, スチレンの $\pi$ 電子から過酸化物の LUMO（酸素-酸素反結合性軌 道）への一電子移動反応が容易に進行するためラジカル 重合は観測されず, $1: 1$ 付加生成物 $\left[\mathrm{PhCH}\left(\mathrm{OCOR}_{\mathrm{F}}\right)-\right.$ $\mathrm{CH}_{2} \mathrm{R}_{\mathrm{F}}$ ] が得られる ${ }^{12)}$ 。

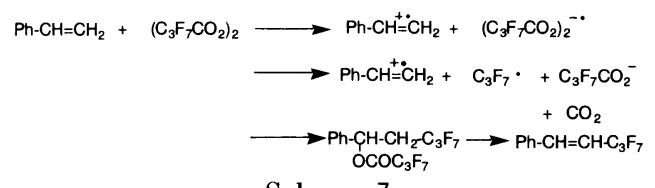

Scheme 7

一方, ラジカル重合性の高いアクリル酸の HOMO の エネルギー準位 $(-11.134 \mathrm{eV})$ はスチレンに比べ著しく 低い。そのため, 一電子移動反応ではなく, 先に示した ビニルシラン類との反応と同様な機構で ${ }^{13)}$, 過酸化物 の熱分解により生成したフルオロアルキルラジカルによ るアクリル酸へのラジカル付加反応が進行し, フルオロ アルキル基が両端に導入された分子量が数千～1 万レベ ルのアクリル酸オリゴマーが得られることがわかっ た ${ }^{14)}$ (Table 1)。

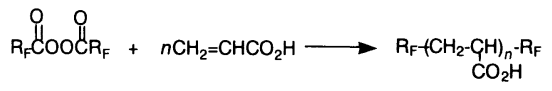

$$
\begin{array}{r}
\mathrm{R}_{\mathrm{F}}=\mathrm{C}_{3} \mathrm{~F}_{7}, \mathrm{C}_{6} \mathrm{~F}_{13}, \underset{\mathrm{CF}_{3}}{\mathrm{CF}\left(\mathrm{OCF}_{2} \mathrm{CF}_{3}-\mathrm{OC}_{3} \mathrm{~F}_{7}\right.} \\
\\
\quad m=0,1,2,3
\end{array}
$$

Scheme 8

同様に, ポリメリックな過酸化フルオロアルカノイル
: - $\left[\mathrm{C}(=\mathrm{O}) \mathrm{R}_{\mathrm{F}} \mathrm{C}(=\mathrm{O}) \mathrm{OO}\right]_{n^{-15}}$ をアクリル酸と反応さ せることにより分子内部にフルオロアルキレン基 $\left(R_{F^{-}}\right)$が直接導入されたアクリル酸オリゴマーが比較 的収率良く得られる ${ }^{16)}$ 。

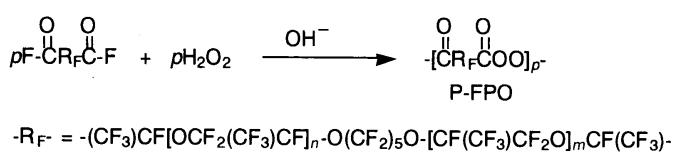
$(n+m=3)$

Scheme 9

これらのフルオロアルキルおよびフルオロアルキレン 基含有アクリル酸オリゴマーは, 水やメタノール, エ夕 ノールおよびテトラヒドロフラン等の水溶性極性溶剂に 可溶である。さらに興味深いことに，界面特性のところ で紹介するが, フルオロアルキル基はオリゴマーの両末 端のみであるにもかかわらず, フッ素に起因した優れた 性質を示す ${ }^{17)}$ 。

アクリル酸誘導体としては, メチルメタクリレート, もしくはポリ(オキシエチレン) ユニット含有メタクリ レート類等のメタクリルエステル類を過酸化フルオロア ルカノイルと反応させることも可能であり，フルオロア ルキル基が導入されたメチルメタクリレートオリゴマー 類が比較的収率良く得られる ${ }^{18)}$ 。

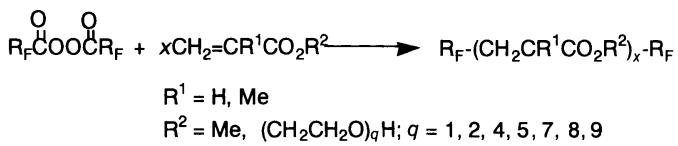
Scheme 10

ところで，フルオロアルキル基含有高分子化合物は， フルオロアルキル基の強い疎水性および疎油性のため一 般に種々の溶剂に対する溶解性が低(19)。従って, 工 ニークな機能が期待されるフルオロアルキル基含有高分 子界面活性剂を幅広く展開させるためには, 種々の溶剂

Table 1 The Reactions of Fluoroalkanoyl Peroxides with Acrylic Acid (ACA).

\begin{tabular}{clcc}
\hline ACA & & \multicolumn{2}{c}{$\mathrm{R}_{\mathrm{F}^{-}\left(\mathrm{CH}_{2} \mathrm{CHCO}_{2} \mathrm{H}\right)_{n}-\mathrm{R}_{\mathrm{F}}}$} \\
$(\mathrm{mmol})$ & $\mathrm{R}_{\mathrm{F}}$ in $\left(\mathrm{R}_{\mathrm{F}} \mathrm{COO}\right)_{2} / \mathrm{mmol}$ & Yield $(\%)^{\mathrm{a})}$ & $\overline{\mathrm{Mn}}(\overline{\mathrm{Mw}} / \overline{\mathrm{Mn}})$ \\
\hline 17 & $\mathrm{CF}\left(\mathrm{CF}_{3}\right)\left[\mathrm{OCF}_{2} \mathrm{CF}\left(\mathrm{CF}_{3}\right)\right]_{2} \mathrm{OC}_{3} \mathrm{~F}_{7}(6.8)$ & 29 & $12800(1.72)$ \\
120 & $\mathrm{CF}\left(\mathrm{CF}_{3}\right) \mathrm{OCF}_{2} \mathrm{CF}\left(\mathrm{CF}_{3}\right) \mathrm{OC}_{3} \mathrm{~F}_{7}(34)$ & 34 & $11200(1.54)$ \\
566 & $\mathrm{CF}\left(\mathrm{CF}_{3}\right) \mathrm{OC}_{3} \mathrm{~F}_{7}(236)$ & 45 & $12000(1.54)$ \\
204 & $\mathrm{C}_{3} \mathrm{~F}_{7}(95)$ & 39 & $5100(1.47)$ \\
69 & $\mathrm{C}_{6} \mathrm{~F}_{13}(29)$ & 26 & $4600(1.43)$ \\
\hline
\end{tabular}

a ) The yields are based on the starting material (acrylic acid) and the decarboxylated peroxide unit $\left(R_{F}-R_{F}\right)$. 
への溶解性をデザインする必要がある。そこで，水やメ 夕ノール等の水溶性極性溶剂以外にベンゼン, トルエン 等の非極性溶剤にも可溶なフルオロアルキル基含有オリ ゴマー類を合成するため, 油溶性コモノマーとのコオリ ゴメリゼーションを検討した。

まず, メチルメタクリレート，エチルメタクリレート 等のアルキルメタクリレート類に注目し，フルオロアル キル基含有アクリル酸コオリゴマーの合成について検討 した ${ }^{20)}$ 。

$$
\begin{aligned}
& \stackrel{\circ}{\mathrm{R}_{\mathrm{F}} \mathrm{COOOC}} \mathrm{O}_{\mathrm{F}}+x \mathrm{CH}_{2}=\mathrm{CMeCO}_{2} \mathrm{R}+\mathrm{yCH}_{2}=\mathrm{CHCO}_{2} \mathrm{H} \longrightarrow \\
& \mathrm{R}_{\mathrm{F}}-\left(\mathrm{CH}_{2}-\mathrm{CMe}\right)_{x}-\left(\mathrm{CH}_{2}-\mathrm{CH}\right)_{y}-\mathrm{R}_{\mathrm{F}} \\
& \mathrm{R}_{\mathrm{F}}=\mathrm{C}_{3} \mathrm{~F}_{7}, \underset{\mathrm{CF}_{3}}{\mathrm{CF}\left(\mathrm{OCF}_{2} \mathrm{CF}_{m}-\mathrm{CC}_{3} \mathrm{~F}_{7} ; m=0,1 \quad \mathrm{R}=\mathrm{Me}, \mathrm{Et}, n-\mathrm{Bu},\right. \text { 2-ethylhexyl, }}
\end{aligned}
$$

Scheme 11

その結果，アルキルセグメントを有する一連のコオリ ゴマー類を合成することができ，これらコオリゴマーは メタノール等の極性溶剤以外にベンゼン，トルエン等の 非極性溶剤に可溶となることがわかった。しかしなが ら，これらコオリゴマーはベンゼン，トルエン等に可溶 となるものの, 逆に水への溶解性が著しく低下した ${ }^{20)}$ 。

次に，油溶性コモノマーとしてトリメチルビニルシラ ンを用いたところ,トリメチルシリルセグメントが導入 されたフルオロシリコンコオリゴマーが比較的収率良く 得られた。

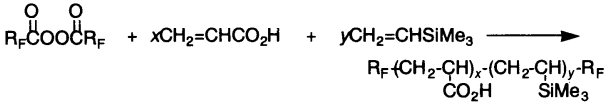

$$
\begin{aligned}
& \mathrm{R}_{\mathrm{F}}=\mathrm{C}_{3} \mathrm{~F}_{7}, \underset{\mathrm{CF}_{3}}{\mathrm{CF}\left(\mathrm{OCF}_{2} \mathrm{CF}_{\mathrm{CF}_{3}} \mathrm{CF}_{3}\right.} \mathrm{OC}_{3} \mathrm{~F}_{7} ; m=0,1,2
\end{aligned}
$$

Scheme 12

このフルオロシリコンコオリゴマーは, 水溶性も良好 でありベンゼン, トルエン等の非極性芳香族溶剤にも可 溶であり, 両親媒性のフルオロシリコン系オリゴマーと して興味深い21)。トリメチルシリル基以外に，ポリシ

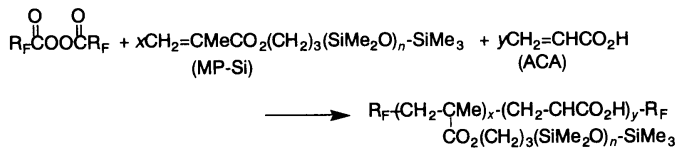

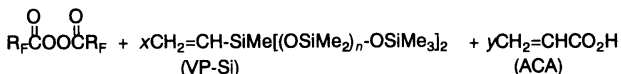

$$
\begin{aligned}
& \longrightarrow \mathrm{R}_{\mathrm{F}}\left(\mathrm{CH}_{2}-\mathrm{CH}\right)_{x}-\left(\mathrm{CH}_{2}-\mathrm{CHCO}_{2} \mathrm{H}\right)_{y} \cdot \mathrm{R}_{\mathrm{F}} \\
& \text { SiMe[(OSiMe } \left.\left.)_{n}\right)_{n}-\mathrm{OSiMe}_{3}\right]_{2}
\end{aligned}
$$$$
\mathrm{R}_{\mathrm{F}}=\mathrm{C}_{3} \mathrm{~F}_{7}, \underset{\mathrm{CF}_{3}}{\mathrm{CF}}\left(\mathrm{OCF}_{2} \mathrm{CF}_{\mathrm{CF}_{3}} \mathrm{OC}_{3} \mathrm{~F}_{7} ; \rho=0,1,2\right.
$$

Scheme 13
ロキサンセグメントを有するフルオロシリコン系コオリ ゴマーの合成も, 過酸化フルオロアルカノイルを用いる ことにより可能である ${ }^{22)}$ 。

ポリシロキサンセグメント含有ホモオリゴマーはフッ 素系以外の溶剤に対して難溶であるのに対し ${ }^{23)}$, この アクリル酸とのコオリゴマーは, ベンゼン, トルエン等 の非極性溶剤にも可溶となる。

一方, 先に示したカルボキシル基を含まない 1,3-ジ ビニルシラン類とアクリル酸との過酸化フルオロアルカ ノイルによるコオリゴメル化反応では, ジビニルシラン 類の環化反応が進行し, 6 員環構造を有するコオリゴ マー (平均分子量 : 1400～8900) が得られる ${ }^{24) 。 ~}$

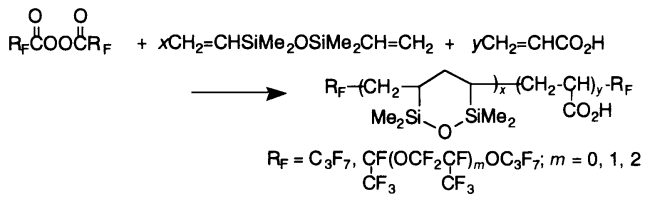

Scheme 14

このコオリゴマーは, トリメチルシリルセグメント含 有アクリル酸コオリゴマーと同様, 水以外にベンゼン,

トルエン等の芳香族系非極性溶剤に可溶である ${ }^{24)}$ 。

$2 \cdot 3$ 非イオン系フルオロアルキル基含有オリゴマー 類の合成

非イオンタイプのフッ素系オリゴマーとして，モルホ リノセグメントを有したフルオロアルキル基含有オリゴ マー (平均分子量 : 1700 7300) を合成した ${ }^{25)}$ 。

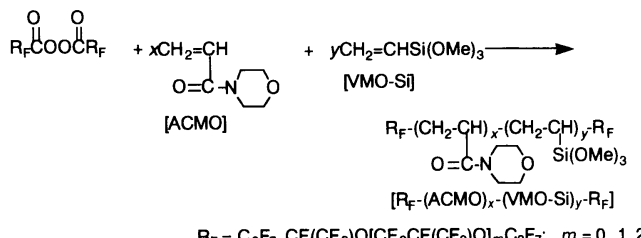

Scheme 15

このモルホリノ基が導入されたオリゴマーは, 水に易 溶であり，さらに興味深いことにへキサンを除いた汎用 の有機溶剤に可溶であることから, 新しい非イオンタイ プの両親媒性高分子界面活性剂として興味がもたれる。

過酸化フルオロアルカノイルはまた, フルオロアルキ ル基含有ビニルアルコールオリゴマー類の合成に応用す ることができる ${ }^{26)}$ 。通常のフッ素を含まないポリ（ビ ニルアルコール）は水溶性であり, 有機溶剤に不溶であ るのに対し, フルオロアルキル基含有ビニルアルコール オリゴマーは水に不溶となるものの, 逆に通常の有機溶 剤に可溶となる。 


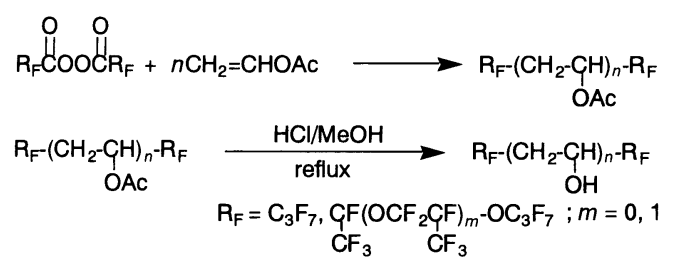

Scheme 16

一般に, アリル化合物はアリルラジカルの共鳴安定性 のため退化的連鎖移動を起こしやすく, ラジカル重合性 に乏しいとされている27)。しかし, 過酸化フルオロア ルカノイルとアリルアルコールあるいはポリ (オキシエ チレン) ユニット含有アリルアルコール類との反応によ り, フルオロアルキル基がやはり両端に導入されたアリ ルアルコールオリゴマー類が得られる ${ }^{28)}$ 。これらアリ ルアルコールオリゴマー類は, 水以外に通常の有機溶剤 に易溶であり, 新規な非イオンタイプのフッ素系界面活 性斑としての展開が期待される。

$$
\begin{aligned}
& n \mathrm{CH}_{2}=\mathrm{CH}-\mathrm{CH}_{2} \mathrm{OR}+\stackrel{\mathrm{O}}{\mathrm{R}} \mathrm{COOOCH}_{\mathrm{F}} \longrightarrow \mathrm{R}_{\mathrm{F}}+\underset{\mathrm{CH}_{2}-\mathrm{CH}_{2} \mathrm{OR}}{\mathrm{CH}_{\mathrm{F}}-\mathrm{R}_{\mathrm{F}}} \\
& \mathrm{R}=\left(\mathrm{CH}_{2} \mathrm{CH}_{2} \mathrm{O}\right)_{q}-\mathrm{H} ; q=0,3 \\
& \mathrm{R}_{\mathrm{F}}=\mathrm{C}_{3} \mathrm{~F}_{7}, \mathrm{CFOCF}_{3} \mathrm{CFOC}_{3} \mathrm{CF}_{7}
\end{aligned}
$$

Scheme 17

\section{$2 \cdot 4$ フルオロアルキル基含有カチオン系オリゴマー 類の合成}

国豊らによれば，長鎖のフルオロアルキル基を有する 二鎖型のカチオン系界面活性剂は, リポソームに相当す る安定な二分子膜 (ベシクル) を基本とする小胞体を形 成しやすいことが報告されており，これら界面活性剂の 合成及びその性質の解明に関する研究が活発に行われて (る ${ }^{29)}$ 。

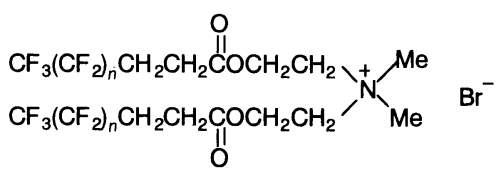

Scheme 18

過酸化フルオロアルカノイルと重合性モノマーとのラ ジカルプロセスで得られるオリゴマー類は, 両端にフル オロアルキル基を有していることから一種の二鎖型界面 活性剂と考えることができるであろう。このような観点 から, 過酸化フルオロアルカノイルを用いたフルオロア ルキル基含有カチオン系高分子界面活性剂の合成を検討 した。

2-アクリロキシエチルトリメチルアンモニウムクロ

$$
\begin{aligned}
& \stackrel{\mathrm{O}}{\mathrm{O}} \stackrel{\mathrm{O}}{\mathrm{F}} \mathrm{COOCR_{F }}+x \mathrm{CH}_{2}=\mathrm{CHCO}_{2}\left(\mathrm{CH}_{2}\right)_{2} \mathrm{~N}^{+} \mathrm{Me}_{3} \mathrm{Cl}^{-} \stackrel{45^{\circ} \mathrm{C} / 5 \mathrm{~h}}{\longrightarrow} \\
& \begin{array}{l}
\mathrm{R}_{\mathrm{F}-}-\left(\mathrm{CH}_{2}-\mathrm{CH}\right)_{x} \cdot-\mathrm{R}_{\mathrm{F}} \\
\quad \mathrm{CO}_{2}\left(\mathrm{CH}_{2}\right)_{2} \mathrm{~N}^{+} \mathrm{Me}_{3} \mathrm{Cl}^{-} \\
{\left[\mathrm{R}_{\mathrm{F}}(\mathrm{AETM})_{n}-\mathrm{R}_{\mathrm{F}}\right]}
\end{array} \\
& \mathrm{R}_{\mathrm{F}}=\mathrm{C}_{3} \mathrm{~F}_{7}, \mathrm{CF}\left(\mathrm{CF}_{3}\right) \mathrm{O}\left[\mathrm{CF}_{2} \mathrm{CF}\left(\mathrm{CF}_{3}\right) \mathrm{O}_{m} \mathrm{C}_{3} \mathrm{~F}_{7} ; m=0,1,2\right. \\
& \text { Scheme } 19
\end{aligned}
$$

リドを用いることにより，二鎖型タイプのフルオロアル キル基含有カチオン系オリゴマーが容易に合成でき $3^{30)}$ 。このフルオロアルキル基含有カチオン系オリゴ マーは, 水溶性であり, さらに水溶性極性有機溶剂にも 可溶である。また, トリメチルビニルシラン等の油溶性 コモノマーを用いたコオリゴマーはベンゼン, トルエン 等の非極性溶剤にも一部可溶となることから，雨親媒性 カチオン界面活性剤としても展開を考えている。

$$
\begin{aligned}
& \stackrel{O}{\stackrel{O}{O}{ }_{\mathrm{F}} \mathrm{COOOCR}} \mathrm{F}_{\mathrm{F}}+x \mathrm{CH}_{2}=\mathrm{CHCO}_{2}\left(\mathrm{CH}_{2}\right)_{2} \mathrm{~N}^{+} \mathrm{Me}_{3} \mathrm{Cl}^{-}+y \mathrm{CH}_{2}=\mathrm{CR}^{1} \mathrm{R}^{2} \stackrel{45^{\circ} \mathrm{C} / 5 \mathrm{~h}}{\longrightarrow} \\
& \mathrm{R}_{\mathrm{F}}\left(\mathrm{CH}_{2}-\mathrm{CH}_{x}-\left(\mathrm{CH}_{2}-\mathrm{CR}^{1} \mathrm{R}^{2}\right) y-\mathrm{R}_{\mathrm{F}}\right. \\
& \text { [RF } \left.(\text { AETM })_{x}-\left(\mathrm{CH}_{2}-\mathrm{CR}^{1} \mathrm{R}^{2}\right)_{y}-\mathrm{R}_{\mathrm{F}}\right] \\
& \left.\mathrm{R}_{\mathrm{F}}=\mathrm{CF}\left(\mathrm{CF}_{3}\right) \mathrm{O}_{[\mathrm{CF}} \mathrm{CF}\left(\mathrm{CF}_{3}\right) \mathrm{O}\right]_{m} \mathrm{C}_{3} \mathrm{~F}_{7} ; m=0,1,2 \\
& R^{1}=\mathrm{H}_{;} \mathrm{R}^{2}=\mathrm{SiMe}_{3} \\
& \mathrm{R}^{1}=\mathrm{Me} ; \mathrm{R}^{2}=\mathrm{CO}_{2} \mathrm{Me}, \mathrm{CO}_{2} \mathrm{Et}, \mathrm{CO}_{2} \mathrm{Bu}
\end{aligned}
$$

アクリル系以外にも, 過酸化フルオロアルカノイルと アリルアミンもしくはジアリルアミン塩酸塩との反応に よりアリルアミンタイプのカチオン系オリゴマー類 $\left[\mathrm{R}_{\mathrm{F}}\right.$ $\left.-(\mathrm{AL}-\mathrm{Am})_{n}-\mathrm{R}_{\mathrm{F}}\right]$ を合成した ${ }^{31)}$ 。特に, ジアリルア ミン塩酸塩との反応により合成されるオリゴマー $\left[\mathrm{R}_{\mathrm{F}}{ }^{-}\right.$ $\left.(\mathrm{DAL}-\mathrm{Am})_{n}-\mathrm{R}_{\mathrm{F}}\right]$ は 5 員環構造を有している (Table 2)。

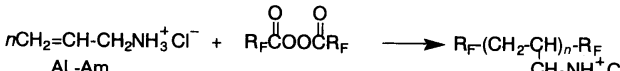

$$
\begin{aligned}
& \begin{array}{l}
\mathrm{AL}-\mathrm{Am} \\
{\left[\mathrm{R}_{\mathrm{F}}-(\mathrm{AL}-\mathrm{Am})_{n}-\mathrm{R}_{\mathrm{F}}\right]}
\end{array}
\end{aligned}
$$

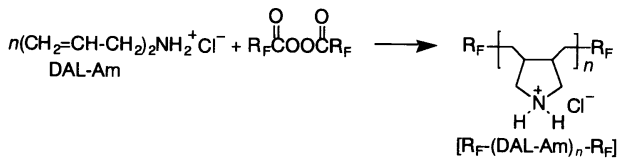

$$
\begin{aligned}
& \left.\mathrm{R}_{\mathrm{F}}=\mathrm{C}_{3} \mathrm{~F}_{7}, \mathrm{CF}_{3} \mathrm{CFCF}_{2} \mathrm{CFF}_{3}\right)_{m}-\mathrm{OC}_{3} \mathrm{~F}_{7} ; m=0,1
\end{aligned}
$$

Scheme 21

スチレンと構造が類似した 4-ビニルピリジンと過酸 化フルオロアルカノイルとの反応においては, スチレン に見られた $1: 1$ 付加生成物は得られず, ピリジン環の

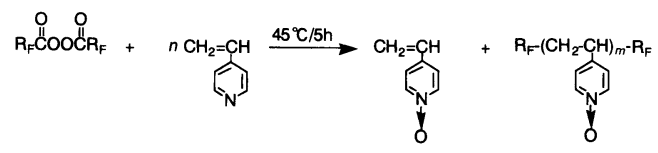

Scheme 22 
Table 2 Reactions of Fluoroalkanoyl Peroxides with Allyl-and Diallyl-ammonium Chlorides.

\begin{tabular}{|c|c|c|c|}
\hline \multirow{2}{*}{$\begin{array}{l}\mathrm{R}_{\mathrm{F}} \text { in Peroxide } \\
(\mathrm{mmol})\end{array}$} & \multirow{2}{*}{$\begin{array}{c}\mathrm{AL}-\mathrm{Am} \text { or } \mathrm{DAL}-\mathrm{Am} \\
(\mathrm{mmol})\end{array}$} & \multicolumn{2}{|c|}{ Product } \\
\hline & & Yield $(\%)^{a)}$ & $\overline{\mathrm{Mn}}(\overline{\mathrm{Mw}} / \overline{\mathrm{Mn}})$ \\
\hline & $\mathrm{AL}-\mathrm{Am}$ & \multicolumn{2}{|c|}{$\mathrm{R}_{\mathrm{F}^{-}}(\mathrm{AL}-\mathrm{Am})_{n}-\mathrm{R}_{\mathrm{F}}$} \\
\hline $\mathrm{C}_{3} \mathrm{~F}_{7}(9)$ & 43 & 1 & $2050(1.43)$ \\
\hline $\mathrm{C}_{3} \mathrm{~F}_{7}(6)$ & 59 & 1 & $3210(1.63)$ \\
\hline $\mathrm{CF}\left(\mathrm{CF}_{3}\right) \mathrm{OC}_{3} \mathrm{~F}_{7}(9)$ & 43 & 6 & $1900(1.82)$ \\
\hline $\mathrm{CF}\left(\mathrm{CF}_{3}\right) \mathrm{OC}_{3} \mathrm{~F}_{7}(8)$ & 76 & 10 & $2640(1.72)$ \\
\hline $\mathrm{CF}\left(\mathrm{CF}_{3}\right) \mathrm{OC}_{3} \mathrm{~F}_{7}(8)$ & 114 & 12 & $3200(1.71)$ \\
\hline $\mathrm{CF}\left(\mathrm{CF}_{3}\right) \mathrm{OC}_{3} \mathrm{~F}_{7}(8)$ & 152 & 14 & $3200(1.72)$ \\
\hline $\mathrm{CF}\left(\mathrm{CF}_{3}\right) \mathrm{OCF}_{2} \mathrm{CF}\left(\mathrm{CF}_{3}\right) \mathrm{OC}_{3} \mathrm{~F}_{7}(9)$ & 43 & 10 & $1300(2.13)$ \\
\hline $\mathrm{CF}\left(\mathrm{CF}_{3}\right) \mathrm{OCF}_{2} \mathrm{CF}\left(\mathrm{CF}_{3}\right) \mathrm{OC}_{3} \mathrm{~F}_{7}(9)$ & 64 & 12 & $1630(2.34)$ \\
\hline $\mathrm{CF}\left(\mathrm{CF}_{3}\right) \mathrm{OCF}_{2} \mathrm{CF}\left(\mathrm{CF}_{3}\right) \mathrm{OC}_{3} \mathrm{~F}_{7}(4)$ & 61 & 17 & $2220(1.71)$ \\
\hline \multirow[t]{2}{*}{$\mathrm{CF}\left(\mathrm{CF}_{3}\right) \mathrm{OCF}_{2} \mathrm{CF}\left(\mathrm{CF}_{3}\right) \mathrm{OC}_{3} \mathrm{~F}_{7}(4)$} & 81 & 10 & $2530(1.84)$ \\
\hline & DAL-Am & \multicolumn{2}{|c|}{$\mathrm{R}_{\mathrm{F}}-(\mathrm{DAL}-\mathrm{Am})_{n}-\mathrm{R}_{\mathrm{F}}$} \\
\hline $\mathrm{C}_{3} \mathrm{~F}_{7}(3)$ & 44 & trace & - \\
\hline $\mathrm{CF}\left(\mathrm{CF}_{3}\right) \mathrm{OC}_{3} \mathrm{~F}_{7}(9)$ & 43 & 29 & $1320(1.69)$ \\
\hline $\mathrm{CF}\left(\mathrm{CF}_{3}\right) \mathrm{OC}_{3} \mathrm{~F}_{7}(4)$ & 43 & 21 & $1500(2.15)$ \\
\hline $\mathrm{CF}\left(\mathrm{CF}_{3}\right) \mathrm{OC}_{3} \mathrm{~F}_{7}(4)$ & 58 & 21 & $1550(2.25)$ \\
\hline $\mathrm{CF}\left(\mathrm{CF}_{3}\right) \mathrm{OCF}_{2} \mathrm{CF}\left(\mathrm{CF}_{3}\right) \mathrm{OC}_{3} \mathrm{~F}_{7}(2)$ & 10 & 44 & $1420(2.22)$ \\
\hline $\mathrm{CF}\left(\mathrm{CF}_{3}\right) \mathrm{OCF}_{2} \mathrm{CF}\left(\mathrm{CF}_{3}\right) \mathrm{OC}_{3} \mathrm{~F}_{7}(2)$ & 20 & 11 & $1430(2.07)$ \\
\hline $\mathrm{CF}\left(\mathrm{CF}_{3}\right) \mathrm{OCF}_{2} \mathrm{CF}\left(\mathrm{CF}_{3}\right) \mathrm{OC}_{3} \mathrm{~F}_{7}(2)$ & 41 & 22 & $2330(2.99)$ \\
\hline
\end{tabular}

a ) The yields were based on the starting materials[allyl-or diallyl-ammonium chloride and the decarboxylated peroxide unit $\left.\left(R_{F}-R_{F}\right)\right]$.

窒素原子から過酸化物への求核反応が進行し, 4-ビニル ピリジンー $N$-オキシドおよびフルオロアルキル基含有4ビニルピリジンー $N$-オキシドオリゴマーが得られた ${ }^{32) 。}$

そこで, 塩酸塩として窒素原子の求核性を抑えて過酸 化フルオロアルカノイルと反応させることにより, 分子 量が数千レベルのフルオロアルキル基含有 $4-$ ビニルピ リジニウムオリゴマーを合成することができた ${ }^{32)}$ 。ピ リジニウムオリゴマーは水溶性であり, さらにメタノー ル等の極性溶剤にも可溶である。

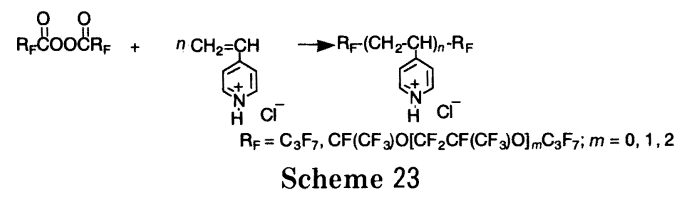

\section{3 フルオロアルキル基含有オリゴマー類の 界面特性}

フッ素系界面活性剂の界面特性に関する研究は数多い が，ほとんどは低分子量のモノマー界面活性剤に関する 研究である。フッ素系高分子界面活性剤については, 最 近の Cochin らによる 2-アクリロキシエチルトリメチ
ルアンモニウムクロリドとフルオロアルキルアクリレー トとのランダムコポリマーによるポリソープの報告があ る程度である ${ }^{33)}$ 。

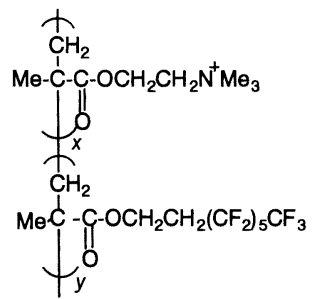

\section{Scheme 24}

本フルオロアルキル基含有オリゴマーの構造上の特色 として, フルオロアルキル基がオリゴマー鎖の両端に選 択的に存在すること, また, オリゴマー主鎖に各種のイ オン性親水基が多数結合していることであり，構造的に は 2 鎖型の界面活性剂と見なすこともできる。この特色 的な構造により, 従来からある高分子界面活性剤とは一 線を隔している。

表面張力およびデカンとの界面張力を測定した代表的 な結果をアクリル酸系 ${ }^{14)}$, EO 付加アリルアルコール 系 ${ }^{28)}$ ，アリルアミンおよびジアリルアミン塩酸塩系オ

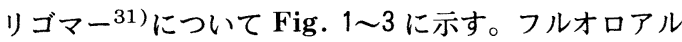




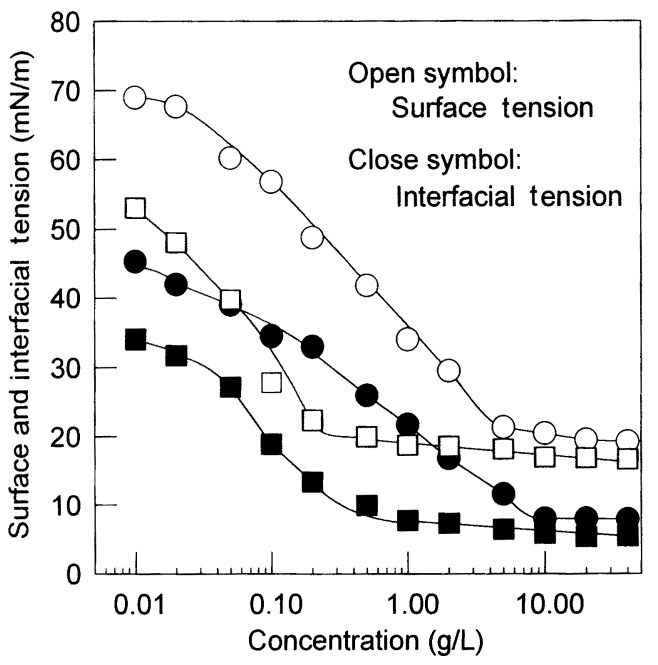

Fig. 1 Surface and Interfacial Tensions of Acrylic Acid Oligomers at $30^{\circ} \mathrm{C}$ (Oil Phase : $n$-decane).
$\mathrm{R}_{\mathrm{f}}=\mathrm{C}_{3} \mathrm{~F}_{7}$
$\mathrm{R}_{\mathrm{f}}=\mathrm{C}_{3} \mathrm{~F}_{7} \mathrm{OCF}\left(\mathrm{CF}_{3}\right)$
- $\mathrm{R}_{\mathrm{f}}=\mathrm{C}_{3} \mathrm{~F}_{7}$
$\mathrm{R}_{\mathrm{f}}=\mathrm{C}_{3} \mathrm{~F}_{7} \mathrm{OCF}\left(\mathrm{CF}_{3}\right)$

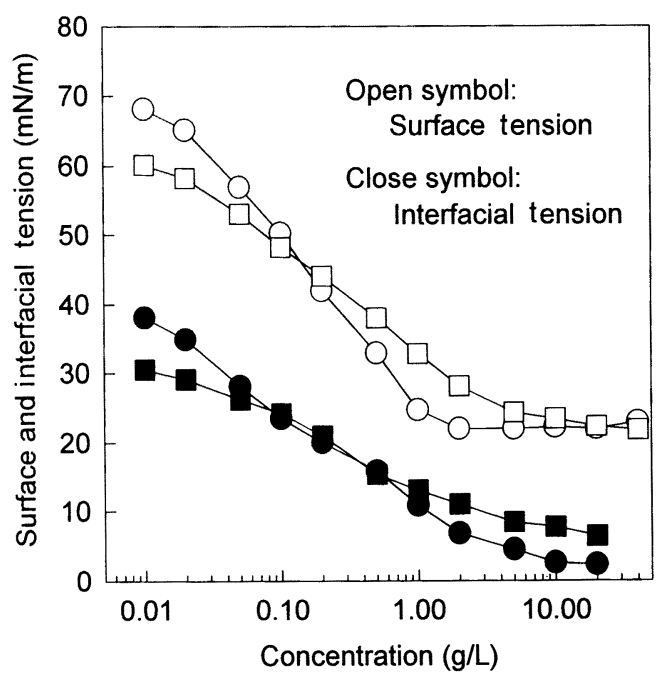

Fig. 2 Surface and Interfacial Tensions of Allyl Ethylene Oxide Ether Oligomers at $30^{\circ} \mathrm{C}$. $\left(\mathrm{R}_{\mathrm{f}}=\mathrm{C}_{3} \mathrm{~F}_{7}\right.$; Oil Phase : $n$-decane $)$
- EO3
E015
- $\mathrm{EO} 3$
E015

キル基を持たないポリアクリル酸やポリアリルアミンは 表面張力低下能が小さいのにたいし，フルオロアルキル 基含有オリゴマー類では低濃度でいずれも非常に優れた 表面及び界面張力低下能を示し, 最終的にはモノマー型 に匹敵する表面張力值を与える。特に，カチオン系では 界面張力を $1 \mathrm{mN} / \mathrm{m}$ 以下にまで下げるものも存在す

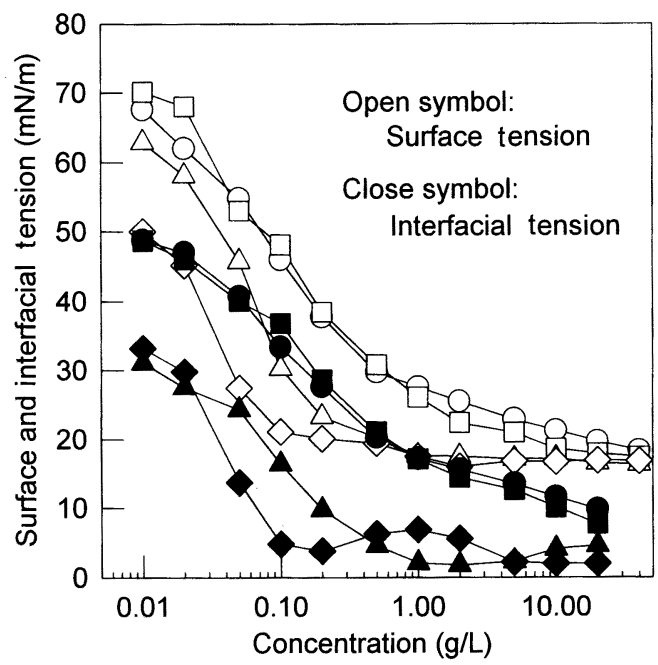

Fig. 3 Surface and Interfacial Tensions of Monoallyl- $\left(\mathrm{NH}_{3}{ }^{+}\right)$and Diallylammonium Chloride $\left(-\mathrm{NH}_{2}{ }^{+}-\right)$Oligomers at $30^{\circ} \mathrm{C}$ (Oil Phase : $n$-decane).

$\mathrm{NH}_{3}{ }^{+} \quad \mathrm{R}_{\mathrm{f}}=\mathrm{C}_{3} \mathrm{~F}_{7} \mathrm{OCF}\left(\mathrm{CF}_{3}\right)$

$\triangle-\mathrm{NH}_{2}{ }^{+}-\mathrm{R}_{\mathrm{f}}=\mathrm{C}_{3} \mathrm{~F}_{7} \mathrm{OCF}\left(\mathrm{CF}_{3}\right)$

$\square \mathrm{NH}_{3}{ }^{+} \quad \mathrm{R}_{\mathrm{f}}=\mathrm{C}_{3} \mathrm{~F}_{7} \mathrm{OCF}\left(\mathrm{CF}_{3}\right) \mathrm{CF}_{2} \mathrm{OCF}\left(\mathrm{CF}_{3}\right)$ $-\mathrm{NH}_{2}{ }^{+}-\mathrm{R}_{\mathrm{f}}=\mathrm{C}_{3} \mathrm{~F}_{7} \mathrm{OCF}\left(\mathrm{CF}_{3}\right) \mathrm{CF}_{2} \mathrm{OCF}\left(\mathrm{CF}_{3}\right)$

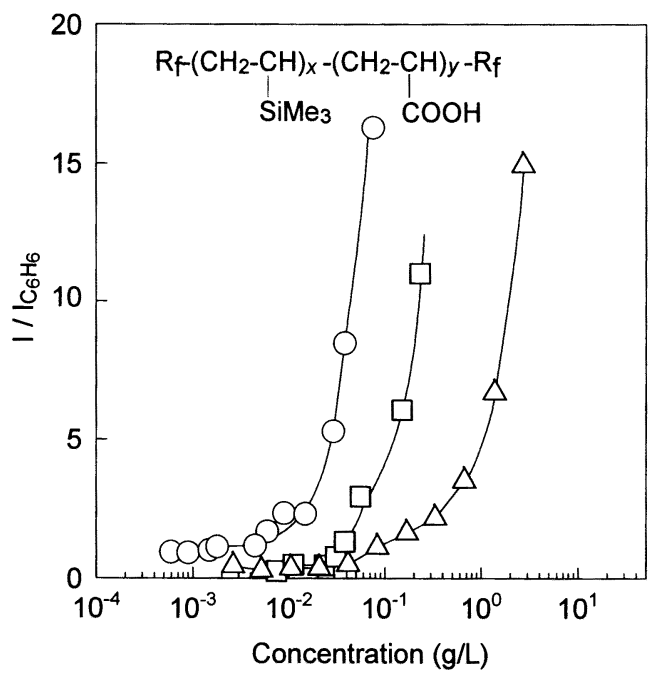

Fig. 4 Relations between $1 / l_{\mathrm{C}_{6} \mathrm{H}_{6}}$ and Concentration of Fluoroalkyl End-capped Oligomer Solution at $30^{\circ} \mathrm{C}$.
$\mathrm{R}_{\mathrm{f}}=\mathrm{C}_{3} \mathrm{~F}_{7}$
$\square \quad \mathrm{R}_{\mathrm{f}}=\mathrm{C}_{3} \mathrm{~F}_{7} \mathrm{OCF}\left(\mathrm{CF}_{3}\right)$
$\triangle \mathrm{R}_{\mathrm{f}}=\mathrm{C}_{3} \mathrm{~F}_{7} \mathrm{OCF}\left(\mathrm{CF}_{3}\right) \mathrm{CF}_{2} \mathrm{OCF}\left(\mathrm{CF}_{3}\right)$

る。しかし, その場合にも乳化は認められないことか ら, フルオロアルキル基の疎油性が大きな要因と考えら れる。 
フルオロアルキル基 $\mathrm{R}_{\mathrm{F}}$ の影響をみると，多くのオリ ゴマーでは, $\mathrm{R}_{\mathrm{F}}=\mathrm{CF}\left(\mathrm{CF}_{3}\right) \mathrm{OC}_{3} \mathrm{~F}_{7}$ が最も優れた低下能 を示す。これは単にフルオロアルキル鎖長のみではな く, 表面や界面におけるフルオロアルキル基の立体的な バルキー性にも依存するためと思われる。

一般に，高分子界面活性剂では濃度の増大とともに表 面張力は徐々に低下するものの明確な $\mathrm{cmc}$ に相当する ような break point を示さない2)。一方，我々のオリゴ マーでは低分子量のフッ素系界面活性剂と同様に明確な break point が存在する。しかし，モノマー型では $\mathrm{cmc}$ 以降は表面張力はほぼ一定值を保つのに比べ，オリゴ マー型では濃度の増大とともに表面張力はさらに低下し ていく。これは水溶液中での立体構造に起因すると考え られる。

阿部らはビニルシランとアクリル酸とのコオリゴマー の光散乱測定を行い, Fig. 4 のように散乱強度が増大し 始める（粒子径か増大し始める）濃度と表面張力が低下 し始める濃度とが一致することを明らかにしている ${ }^{34) 。 ~}$ また, 還元粘度一濃度の関係を調べると, すべてのオリ ゴマーは典型的な水溶性高分子電解質のパターンを与 え，その変曲点は表面張力が低下し始める濃度および散 乱強度が変化し始める濃度とほぼ一致している ${ }^{35)}$ 。水 溶性高分子電解質は，水中ではコイル構造を取るが，本
オリゴマー類でも親水基部分はコイル構造をとり, 両端 のフルオロアルキル基は空気中へ突き出す形となって水 面に並ぶと考えられる。このコイルは一種のばねの様な ものであり, 表面濃度が高くなると縮んでより多くのフ ルオロアルキル基が表面に配向するようになり, 表面張 力が break point 以降でも徐々に低下し続けると考え られる。

フッ素系界面活性剂の界面機能として, 消泡性もその 一つである。各種のオリゴマーについて調べた結果を Table 3に示す。いずれも非常に優れた消泡性を示して おり, EO 付加アリルアルコールオリゴマーを SDS に 混合した場合, わずか $0.2 \%$ の添加でも著しく起泡が抑 えられる ${ }^{36)}$ 。

以上の様に含フルオロアルキルオリゴマーは, フルオ ロアルキル基の効果を充分に発揮させる構造をしてお り, シランカップリング剂の結果などでも従来のフッ素 系化合物よりも優れた点も多く見いだされている。今 後, 表面改質剂としての幅広い応用展開が期待される。

\section{4 フルオロアルキル基含有オリゴマー類の 生理活性}

一般に，アニオンもしくはカチオン性高分子化合物は

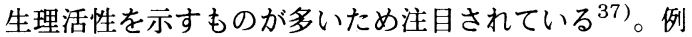

Table 3 Results of Foam Test of Various Surfactants by Improved Semimicro TK method (Unit : $\mathrm{mL}$ ).

\begin{tabular}{|c|c|c|c|c|}
\hline \multirow{2}{*}{ Surfactant } & & \multicolumn{3}{|c|}{ Concentration (\%) } \\
\hline & & 1.0 & 0.5 & 0.1 \\
\hline SDS & & $250(220)$ & $220(165)$ & $90(10)$ \\
\hline C12EO8 & & $215(5)$ & & $165(10)$ \\
\hline DTAC & & $185(5)$ & & \\
\hline $\begin{array}{c}\mathrm{R}_{\mathrm{f}}-\left(\mathrm{CH}_{2} \mathrm{CH}\right)_{m}-\mathrm{R}_{\mathrm{f}} \\
\mathrm{COONa}\end{array}$ & $\mathrm{R}_{\mathrm{f}}=\mathrm{C}_{3} \mathrm{~F}_{7}$ & $0(0)$ & $0(0)$ & $0(0)$ \\
\hline \multirow{2}{*}{$\begin{array}{c}\mathrm{R}_{\mathrm{f}}-\left(\mathrm{CH}_{2} \underset{\uparrow}{\mathrm{CH}}\right)_{m}-\mathrm{R}_{\mathrm{f}} \\
\mathrm{COOH}\end{array}$} & $\mathrm{R}_{\mathrm{f}}=\mathrm{C}_{3} \mathrm{~F}_{7}$ & $0(0)$ & $0(0)$ & $0(0)$ \\
\hline & $\begin{array}{r}\mathrm{R}_{\mathrm{f}}=\mathrm{C}_{3} \mathrm{~F}_{7} \mathrm{OCF} \\
\mathrm{CF}_{3}\end{array}$ & $140(140)$ & $130(10)$ & $20(10)$ \\
\hline \multirow{2}{*}{$\begin{aligned} \mathrm{C}_{3} \mathrm{~F}_{7}-\left(\mathrm{CH}_{2} \mathrm{CH}\right)_{m}-\mathrm{C}_{3} \mathrm{~F}_{7} \\
\mathrm{CH}_{2} \mathrm{O}\left(\mathrm{CH}_{2} \mathrm{CH}_{2} \mathrm{O}\right)_{n} \mathrm{H}\end{aligned}$} & $n=3$ & $0(0)$ & $0(0)$ & $0(0)$ \\
\hline & $n=15$ & $3(0)$ & $0(0)$ & $0(0)$ \\
\hline $\begin{array}{r}\mathrm{R}_{\mathrm{f}}-\left(\mathrm{CH}_{2} \mathrm{CH}\right)_{m}-\mathrm{R}_{\mathrm{f}} \\
\mathrm{CH}_{2} \mathrm{NH}_{3}{ }^{+} \mathrm{Cl}^{-}\end{array}$ & $\begin{array}{r}\mathrm{R}_{\mathrm{f}}=\mathrm{C}_{3} \mathrm{~F}_{7} \mathrm{OCF} \\
\mathrm{CF}_{3}\end{array}$ & $0(0)$ & $0(0)$ & $0(0)$ \\
\hline $\mathrm{CH}_{\mathrm{H}} \mathrm{H}_{m} \mathrm{R}$ & 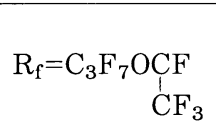 & $0(0)$ & $0(0)$ & $0(0)$ \\
\hline
\end{tabular}

All values in parentheses are foam height after 5 minutes. 
えば，デキストラン硫酸等の硫酸エステル構造を有する 硫酸化多糖類が in vitro の系において高分子系抗エイ ズウイルス薬として有用であることが今までに報告され ている38)。

そこで, フルオロアルキル基含有アクリル酸ホモオリ ゴマー類 $\left[\mathrm{R}_{\mathrm{F}}-\left(\mathrm{CH}_{2} \mathrm{CHCO}_{2} \mathrm{H}\right)_{n}-\mathrm{R}_{\mathrm{F}}\right]$ の抗エイズウイ ルス活性について検討を行った ${ }^{39)}$ 。通常のフッ素を含 まないアクリル酸オリゴマーは抗エイズ活性を示さない ことが知られている ${ }^{40)}$ 。鎖長の短いフルオロアルキル 基 [例えば, $\mathrm{R}_{\mathrm{F}}=\mathrm{C}_{3} \mathrm{~F}_{7}, \mathrm{CF}\left(\mathrm{CF}_{3}\right) \mathrm{OC}_{3} \mathrm{~F}_{7}$ ] を有する オリゴマーでは活性が認められないが, 鎖長の長いフル オロアルキル基, 例えば, $\mathrm{R}_{\mathrm{F}}=\mathrm{CF}\left(\mathrm{CF}_{3}\right)\left[\mathrm{OCF}_{2} \mathrm{CF}\right.$ $\left.\left(\mathrm{CF}_{3}\right)\right]_{3} \mathrm{OC}_{3} \mathrm{~F}_{7}$ を有するオリゴマーにおいてはデキス
トラン硫酸とほぼ同等の活性が得られた ${ }^{39)}$ 。

デキストラン硫酸の作用機序としては, ポジィティブ に荷電したエイズウイスル中の GP-120 への吸着阻害 効果によるものと考えられている ${ }^{39)}$ 。フルオロアルキ ル基含有アクリル酸オリゴマー類ではフッ素の強い電子 吸引性のため酸性度（アニオン性）が高まることから, 活性が発現されたと考えている。さらに, フルオロアル キル基含有アクリル酸コオリゴマー, 特にシリコンセグ メントが導入されたフリオロシリコンコオリゴマーにお いては, 以下の Table 4 に示すように, 抗エイズ活性 が対応するホモオリゴマーさらにはデキストラン硫酸よ り高まることから別の作用機序が関与している可能性も ある。

Table 4 Anti-HIV Activity of $\mathrm{R}_{\mathrm{F}}-\left(\mathrm{CH}_{2}-\mathrm{CHSiMe}_{3}\right)_{x}-\left(\mathrm{CH}_{2} \mathrm{CHCO}_{2} \mathrm{H}\right)_{y}-\mathrm{R}_{\mathrm{F}}$ in MT 4 Cells.

\begin{tabular}{|c|c|c|c|}
\hline $\mathrm{R}_{\mathrm{F}}$ & $\overline{\mathrm{Mn}}(\overline{\mathrm{Mw}} / \overline{\mathrm{Mn}})[x: y]$ & $\begin{array}{c}\left.\mathrm{EC}_{50}{ }^{\mathrm{a}}\right) \\
(\mu \mathrm{g} / \mathrm{mL})\end{array}$ & $\begin{array}{c}\left.\mathrm{CC}_{50} \mathrm{~b}\right) \\
(\mu \mathrm{g} / \mathrm{mL})\end{array}$ \\
\hline \multicolumn{4}{|l|}{$\mathrm{C}_{3} \mathrm{~F}_{7}$} \\
\hline & $1480(1.45)[20: 80]$ & 3.9 & $>100$ \\
\hline & $1860(1.83)[13: 87]$ & 2.2 & $>100$ \\
\hline & $6210(2.02)[4: 96]$ & 42 & $>100$ \\
\hline & $6600(1.94)[3: 97]$ & 67 & $>100$ \\
\hline & $5100(1.47)[0: 100]$ & $>100$ & $>100^{\mathrm{c})}$ \\
\hline \multicolumn{4}{|l|}{$\mathrm{C}_{3} \mathrm{~F}_{7} \mathrm{OCF}\left(\mathrm{CF}_{3}\right)$} \\
\hline & $4180(1.65)[44: 56]$ & $>100$ & $>100$ \\
\hline & $4010(1.61)[35: 65]$ & 16 & $>100$ \\
\hline & $3500(1.45)[35: 65]$ & 42 & $>100$ \\
\hline & $3300(1.41)[26: 74]$ & 12 & $>100$ \\
\hline & $2510(1.25)[24: 76]$ & 5.5 & $>100$ \\
\hline & $3770(1.55)[18: 82]$ & 1.8 & $>100$ \\
\hline & $6070(2.29)[15: 85]$ & 2.2 & $>100$ \\
\hline & $4240(1.23)[13: 87]$ & 2.1 & $>100$ \\
\hline & $7510(2.10)[4: 96]$ & 7.2 & $>100$ \\
\hline & $8000(1.76)[3: 97]$ & 12 & $>100$ \\
\hline & $12000(1.54)[0: 100]$ & $>100$ & $\left.>100^{c}\right)$ \\
\hline \multicolumn{4}{|c|}{$\mathrm{C}_{3} \mathrm{~F}_{7} \mathrm{OCF}\left(\mathrm{CF}_{3}\right) \mathrm{CF}_{2} \mathrm{OCF}\left(\mathrm{CF}_{3}\right)$} \\
\hline & $5030(1.39)[15: 85]$ & 8.3 & $>100$ \\
\hline & $9200(2.10)[0: 100]$ & 29 & $>100^{c)}$ \\
\hline \multicolumn{4}{|c|}{$\mathrm{C}_{3} \mathrm{~F}_{7} \mathrm{OCF}\left(\mathrm{CF}_{3}\right) \mathrm{CF}_{2} \mathrm{OCF}\left(\mathrm{CF}_{3}\right) \mathrm{CF}_{2} \mathrm{OCF}\left(\mathrm{CF}_{3}\right)$} \\
\hline & $5670(1.25)[9: 91]$ & 8.9 & $>100$ \\
\hline & $6300(1.80)[0: 100]$ & 8.5 & $>100^{c)}$ \\
\hline Dextran sulfate & 5000 & 3.5 & $>100$ \\
\hline
\end{tabular}

a ) Fifty percent effective concentration, based on the inhibition of HIV-1induced cytopathic effects in MT-4 cells

b ) Fifty percent cytotoxic concentration, based on the impairment of viability of mock-infected MT-4 cells

c) See Ref. 39 
特に，ホモオリゴマーでは見られなかった鎖長の短い フルオロアルキル基の場合でも, フルオロシリコンコオ リゴマーとすることで活性が見られたことは興味深い。 さらに, 興味深いことに, $\mathrm{R}_{\mathrm{F}}=\mathrm{C}_{3} \mathrm{~F}_{7}, \mathrm{CF}\left(\mathrm{CF}_{3}\right) \mathrm{OC}_{3} \mathrm{~F}_{7}$ を有するコオリゴマーにおいては, シリコン含有量と抗 エイズ活性との間に相関関係があり, シリコン含有量が 共重合比でそれぞれ $13 \%$ および $18 \%$ のとき, 最も活性 が高くなることがわかった。これは，コオリゴマーと GP-120 との相互作用にコオリゴマーの油溶性が影響す ることを意味する ${ }^{20)}$ 。

従来より，第四級アンモニウム塩あるいはホスホニウ 厶塩型高分子化合物は抗菌活性を有することが報告され ている ${ }^{41)}$ 。特に, 高分子系抗菌活性剂は, 低分子抗菌 剂にない大きな特徵, すなわち, 高分子の特性に基づく 活性基の高密度化, 分子サイズの增加による低毒性化及 び高分子材料としてのアプローチが可能な点に特徴があ るものの, 今までにフッ素に起因した優れた機能が同時 に付与された高分子系抗菌剤の合成例はあまり報告され ていない。そこで, 我々はフッ素系高分子抗菌剤として フルオロアルキル基含有トリメチルアンモニウムオリゴ マー類 ${ }^{30)}$ ，アリルおよびジアリルアンモニウムオリゴ マー類の抗菌活性について検討を行った ${ }^{42)}$ 。これらオ リゴマー類は黄色ブドウ球菌に対し抗菌活性を示し, 特 にジアリルアンモニウムオリゴマーは緑膿菌に対しても 高い抗菌活性を示すことを見いだした。これらオリゴ マー類は優れた界面活性剤でもあり, フッ素の機能さら には抗菌活性を同時に付与する新しい機能性材料として の展開が期待される。

\section{5 おわりに}

過酸化フルオロアルカノイルをフルオロアルキル基導 入化剂とすることにより, フルオロアルキル基が両端に 直接導入されたオリゴマー類が比較的温和な条件下で合 成することができた。これらフルオロアルキル基含有オ リゴマーは, 従来のフッ素系高分子化合物と異なり種々 の溶剂に対する溶解性が著しく向上する。特に, フルオ ロアルキル基がオリゴマー末端のみに置換された構造上 の特色を有し，フッ素系低分子界面活性剂とほぼ同等の 界面物性を示すなど, 新しい高分子界面活性剂としての 展開が大いに注目される。

カルボキシル基さらにはカチオンセグメントを有する フルオロアルキル基含有オリゴマー類は抗エイズ活性や 抗菌活性等の生理活性を有しており,これら材料は新し い機能性材料としての展開が期待される。

（受付: 1996 年 4 月 15 日, 受理 : 1996 年 6 月 6 日）

\section{文 献}

1）藤本武彦, “新 - 界面活性剂人門”, 三洋化成工業(株), p. 147 (1981).

2) P. Anton, P. Koberle, A. Laschewsky, Makromol. Chem., 194, 1 (1993); P. Koberle, A. Laschewsky, T.D. Lomax, Makromol. Chem., Rapid. Commun., 12, 427 (1991); P. Koberle, A. Laschewsky, D. van den Boogaard, Polymer, 33, 4029 (1992); A. Laschewsky, I. Zerbe, Polymer, 32, 2081 (1991).

3) 梅本照雄, 有合化, 44, 883 (1986).

4) H. Sawada, J. Fluorine Chem., 61, 253 (1993); H. Sawada, "Review on Heteroatom Chemistry" (Ed. S. Oae), Vol. 8, Myu, Tokyo (1993), p. 205.

5) H. Sawada, M. Nakayama, O. Kikuchi, Y. Yokoyama, J. Fluorine Chem., 50, 393 (1990).

6) M. Yoshida, H. Amemiya, M. Kobayashi, H. Sawada, H. Hagii, K. Aoshima, J. Chem. Soc., Chem. Commun., 1985, 234 ; H. Sawada, M. Yoshida, H. Hagii, K. Aoshima, M. Kobayashi, Bull. Chem. Soc. Jpn., 59, 215 (1986).

7) H. Sawada, M. Mitani, M. Nakayama, M. Yoshida, N. Kamigata, Polymer, 31, 63 (1990); H. Sawada, M. Nakayama, J. Fluorine Chem., 51, 117 (1991).

8）小方芳郎, “有機過酸化物の化学”, 南江堂 (1973).

9) H. Sawada, M. Nakayama, M. Yoshida, T. Yoshida, N. Kamigata, J. Fluorine Chem., 46, 423 (1990).

10) H. Sawada, M. Nakayama, J. Chem. Soc., Chem. Commun., 1991，677; 沢田英夫, Y.-F. Gong, 松本竹 男, 中山雅陽, 小杉正紀, 右田俊彦, 油化学, 40, 730 (1991).

11) T. Kawase, T. Fujii, M. Minagawa, H. Sawada, M. Nakayama, J. Adhesion Sci. Technology, in press (1996).

12) M. Yoshida, K. Moriya, H. Sawada, M. Kobayashi, Chem. Lett., 1985, 755.

13) H. Sawada, Y. Minoshima, H. Nakajima, J. Fluorine Chem., 65, 169 (1993).

14) H. Sawada, Y.-F. Gong, Y. Minoshima, T. Matsumoto, M. Nakayama, M. Kosugi, T. Migita, J. Chem. Soc., Chem. Commun., 1992, 537.

15) H. Sawada, E. Sumino, M. Oue, M. Mitani, H. Nakajima, M. Nishida, Y. Moriya, J. Chem. Soc., Chem. Commun., 1994, 143.

16) H. Sawada, E. Sumino, M. Oue, M. Baba, T. Ki ra, S. Shigeta, M. Mitani, H. Nakajima, M. Nishida, Y. Moriya, J. Fluorine Chem., 74, 21 (1995).

17）沢田英夫, 菩島義浩, Y.-F. Gong, 松本竹男, 小杉正 紀, 右田俊彦, 油化学, 41, 649 (1992).

18) H. Sawada, Y.-F. Gong, T. Matsumoto, M. Kosugi, T. Migita, Chem. Lett., 1992, 531.

19）押部義宏, 石垣秀世, 大村 博, 山本 隆, 高分子論文 集, 46, 81 (1989); Z.-Y. Yang, A.E. Feiring, B.E. Smart, J. Am. Chem. Soc., 116, 4135 (1994).

20) H. Sawada, K. Tanba, N. Itoh, C. Hosoi, M. Oue, M. Baba, T. Kawase, M. Mitani, H. Nakajima, J. Fluorine Chem., 77, 51 (1996). 
21) H. Sawada, N. Itoh, T. Kawase, M. Mitani, H. Nakajima, M. Nishida, Y. Moriya, Langmuir, 10, 994 (1994).

22) H. Sawada, A. Ohashi, M. Oue, M. Abe, M. Mitani, H. Nakajima, M. Nishida, Y. Moriya, J. Jpn. Oil Chem. Soc., 43, 1097 (1994); H. Sawada, A. Ohashi, M. Oue, M. Baba, M. Abe, M. Mitani, H. Nakajima, J. Fluorine Chem., 75, 121 (1995).

23) M. Abe, K. Matsuda, K. Ogino, H. Sawada, K. Nishiyama, Langmuir, 9, 2755 (1993).

24）沢田英夫, 山本恵司, 大植正敏, 川瀬徳三, 早川由夫, 馬場昌範, 三谷元宏, 油化学, 45, 37 (1996).

25) H. Sawada, T. Kawase, Y. Ikematsu, Y. Ishii, M. Oue, Y. Hayakawa, J. Chem. Soc., Chem. Commun., 1996, 179.

26) H. Sawada, K. Yamaguchi, M. Mitani, H. Nakajima, M. Nishida, Y. Moriya, Polymer, 35, 444 (1994); 沢田英夫, 山口佳織, 三谷元宏, 中島弘充, 西 田真佐美, 森屋泰夫, 材料技術, 13, 176 (1995)。

27) R. Laible, Chem. Rev., 58, 807 (1958).

28) H. Sawada, K. Tanba, M. Oue, T. Kawase, M. Mitani, Y. Minoshima, H. Nakajima, M. Nishida, Y. Moriya, Polymer, 35, 4028 (1994).

29) T. Kunitake, Angew. Chem. Int. Ed. Engl. 31, 709, (1992); T. Kunitake, Y. Okahata, S. Yasunami, J. Am. Chem. Soc., 104, 5547 (1982); T. Kunitake, N. Higashi, T. Kajiyama, Chem. Lett., 1984, 717 ; T. Kunitake, N. Higashi, J. Am. Chem. Soc., 107, 692 (1985); H. Trabelsi, S. Szonyi, M. Gaysinski, A. Cambon, H.J. Watzke, Langmuir, 9, 1201 (1993); H. Kuwahara, M. Hamada, Y. Ishikawa, T. Kunitake, J. Am. Chem. Soc., 115, 3002 (1993) ; 東 伸行, 国武豊喜, 膜, 10, 138 (1985).

30）沢田英夫, 片山慎介, 大植正敏, 川瀬徳三, 早川由夫,
馬場昌範, 冨田敏夫, 三谷元宏, 油化学, 45, 161 (1996).

31) H. Sawada, K. Tanba, M. Oue, T. Kawase, Y. Hayakawa, M. Mitani, Y. Minoshima, M. Nishida, Y. Moriya, Polymer, 36, 2103 (1995).

32) H. Sawada, A. Wake, M. Oue, T. Kawase, Y. Hayakawa, Y. Minoshima, M. Mitani, J. Colloid Interface Sci., 178, 379 (1996).

33) D. Cochin, P. Hendlinger, A. Laschewsky, Colloid Polym. Sci., 273, 1138 (1995).

34）阿部正彦, 中川順平, 加茂川恵司, 川瀬徳三，沢田英 夫, 第 33 回油化学討論会・研究発表会講演要旨集, $p$. 50 (1994); 阿部正彦, 中川順平, 吉原慶一, 加茂川恵 司, 桃澤信之, 酒井秀樹, 川瀬徳三, 沢田英夫, 佐野 洋,第 34 回油化学討論会講演要旨集, p. 34 (1995).

35） 川瀬徳三, 沢田英夫, 未発表.

36）川瀬徳三, 沢田英夫, 丹葉敬一, 森屋泰夫, 日本化学 会, 第 69 春季年会講演予稿集 II, p. 714 (1995).

37）砂本順三, 森 文男, “高分子医薬”, 高分子学会 (1992).

38) M. Baba, M. Nakajima, D. Shols, R. Pauwels, J. Balzarini, E. De Clercq, Antiviral Res., 9, 335 (1988); M. Baba, R. Pauwels, J. Balzarini, J. Arnout, J. Desmyter, E. De Clercq, Proc. Natl. Acad. Sci. U.S.A., 85, 339 (1988).

39) M. Baba, T. Kira, S. Shigeta, T. Matsumoto, H. Sawada, J. Acquir. Immune Defic. Syndr., 7, 24 (1994).

40) K. Mizumoto, I. Sugawara, W. Ito, T. Kodama, M. Hayami, S. Mori, Jpn. J. Exp. Med., 58, 145 (1988).

41）金澤昭彦, 池田富樹, 遠藤 剛, 表面, 32, 638 (1994).

42）沢田英夫, 丹葉敬一, 大植正敏, 川瀬徳三, 冨田敏夫, 早川由夫, 三谷元宏, 第 34 回油化学討論会要旨集, p. 60 (1995) 


\title{
日本油化学会誌本号掲載 論文要旨
}

\section{[総説 $]$}

\section{新規界面活性剂の研究開発}

\author{
荻 野 圭 三 \\ 東京理科大学理工学部 ( 278 千葉県野田市山崎 2641)
}

界面活性剂は, 洗浄剤, 乳化, 浮遊選鉱, 泡制御, 表面のぬれ改質, 及び界面活性剂をベースにした分離プロセ ス等, 多くの用途に広く用いられている。界面活性剤の化学とその応用分野は今や非常に莫大であり, 最近, 非常 に多くの興味ある進展が見られる。界面活性剂は普通，化学的には親水基の性質によって，アニオン，カチオン， 両性及び非イオンの型に分類される。一方, 疎水基の性質は通常, 親水基のようにはっきりしない。疎水基は一般 に，長鎖の炭化水素基が多いが，ポリシロキサンやペルフルオロアルキル基も用いられている。最近，炭化水素基 とフッ化炭素基の両方をもつハイブリッド型界面活性剤も開発されている。さらに，精巧な有機合成と酵素反応に よって多くの他の機能性界面活性剤も新しく開発されつつあり，ここでは界面活性剤について概説，特に最近の新 規界面活性剤の研究開発について述べる。

（連絡者 : 荻野圭三) Vol. 45, No. 10, 921 (1996).

\section{[総説］ 多疎水鎖多親水基型イオン性界面活性剂の合成と物性}

\author{
中辻洋 司・池田功 \\ 大阪大学大学院工学研究科分子化学専攻 (下565 吹田市山田丘 $2-1)$
}

二つまたは三つの親水基をもつ二鎖あるいは三鎖型界面活性剤（スルホン酸塩，硫酸エステル塩，リン酸エステ ル塩, カルボン酸塩, アンモニウム塩, タウリン型）を汎用法に準拠して合成し，その界面物性を対応する一鎖一 親水基界面活性剂と比較した。前者は後者に比して, はるかにミセル形成能, 表面張力低下能に優れ, 水溶性も良 好であった。これの知見は分子内及び分子間相互作用の違いから合理的に説明できる。二つあるいは三つの一鎖 一親水基型界面活性剂を単に適当な連結基で束ねるという本構造修飾法は, 界面活性剂の分子設計に極めて有用と 思われる。

（連絡者：池田 功）Vol. 45, No. 10, 933 (1996).

\section{[総説 $]$}

\section{フッ素系高分子界面活性剂}

沢田 英 夫*1 $・$ 瀬 徳 三*2

*1 奈良工業高等専門学校 化学工学科 (开639-11 大和郡山市矢田町)

$* 2$ 大阪市立大学 生活科学部 (宁558 大阪市住吉区杉本)

過酸化フルオロアルカノイルを合成中間体とした一連のフルオロアルキル基含有オリゴマー類の合成およびその 性質に関して解説を行った。フルオロアルキル基含有アクリル酸, ノニオンおよびカチオン系オリゴマー類の合成 方法を紹介した。これらフルオロアルキル基含有オリゴマーにおいて，特にフルオロアルキル基含有アクリル酸， ノニオンおよびカチオン系オリゴマーは, 一般に水以外に, メタノール, エタノール, ジメチルスルホキシド, ベ ンゼン, トルエンに可溶となることが示された。これらフルオロアルキル基含有オリゴマー類は非常にユニークな 構造，すなわちフルオロアルキル基がオリゴマー鎖の両末端のみに置換した構造をしており，この点から二鎖型の 界面活性剂と見なすことができる。これらオリゴマーは，フルオロアルキル基に起因した優れた表面活性，すなわ ち表面および界面張力を著しく低下させることができ, さらには消泡性等の性質をも有する。 
フルオロアルキル基含有アクリル酸ホモおよびコオリゴマーはin vitro の系において有用な抗エイズ活性を示 すことが見いだされた。さらに，フルオロアルキル基含有カチオン系オリゴマー類は抗菌活性を示すことが見いだ された。従って，これらフルオロアルキル基含有アクリル酸およびカチオン系オリゴマー類は，フッ素に起因した ユニークな性質以外に，抗エイズ活性あるいは抗菌活性等の性質を有した新しい機能性材料として種々の分野へ幅 広く展開させることができる。

（連絡者：沢田英夫）Vol. 45, No. 10, 939 (1996).

\title{
[総説 $]$
}

\section{両親媒性高分子の自己組織化と溶液物性}

\author{
森 島 洋太郎 \\ 大阪大学理学部 ( 5560 豊中市待兼山町 1-1)
}

本総説では, 親水性モノマーと疎水性モノマーのラジカル共重合, または水溶性ポリマーの疎水性化合物による 化学修飾法などにより合成が容易な両親媒性ポリマーの自己組織化に焦点を絞って述べる。これらのポリマーは, 水溶液中において，化学構造の違いにより分子内または分子間での疎水基会合に基づいて様々な様式の自己組織化 を示す。自己組織化に及ぼす構造要因としては，ポリマー中の踈水基含量，踈水基と親水基の鎖上分布，疎水基と 主鎖とのスペーサー結合などが重要であり，自己組織化の結果，種々な形のミセルを形成する。高分子の構造とミ セルの構造との関係についても述べる。

（連絡者: 森島洋太郎）Vol. 45, No. 10, 951 (1996).

\section{［総説］＼cjkstart胆汁酸塩のコロイド界面化学的性質}

\section{上 野 實 ${ }^{* 1, * 2}$ ・浅 野 浩 志*3}

*1 東京理科大学理学部第 I 部応用化学科 (干162 東京都新宿区神楽坂 1-3)

*2 東京理科大学界面科学研究所 (下162 東京都新宿区神楽坂 1-3)

*3 日本メナード化栍品(株)総合研究所 (广451 名古屋市西区鳥見町 2-7)

近年, 生体内で生合成される胆汁酸塩は，いろいろな分野，例えば化精品，医薬品，化学工業製品などに可溶化 剤, 乳化剂または分散剂として利用されることが多くなってきている。それに伴い胆汁酸塩水溶液の界面化学的性 質に関する報文や総説も，これまで数多く報告されている。胆汁酸塩は, 分子内に疎水基としてかさ(嵩)高いステ ロイド環を有し，そのアルキル鎖末端の 17 位にカルボキシル基が結合した分子構造をとるために，通常の直鎖の 界面活性剂とは異なった界面化学的性質を示す。さらに，その性質は，ステロイド環に配位したヒドロキシル基の 個数之位置や配置の仕方にも依存する。今回の総説では，この特異的な胆汁酸塩分子の構造が，どのように界面科 学的性質に反映されてくるかを, 基本的な測定と応用例の結果から議論する。

（連絡者：上野 實）Vol. 45, No. 10, 961 (1996).

\section{化学分解性界面活性剂の合成亡物性}

\author{
武田 德 司
}

大阪市立工業研究所（ $\bar{\top} 536$ 大阪市城東区森ノ宮 1-6-50) 